
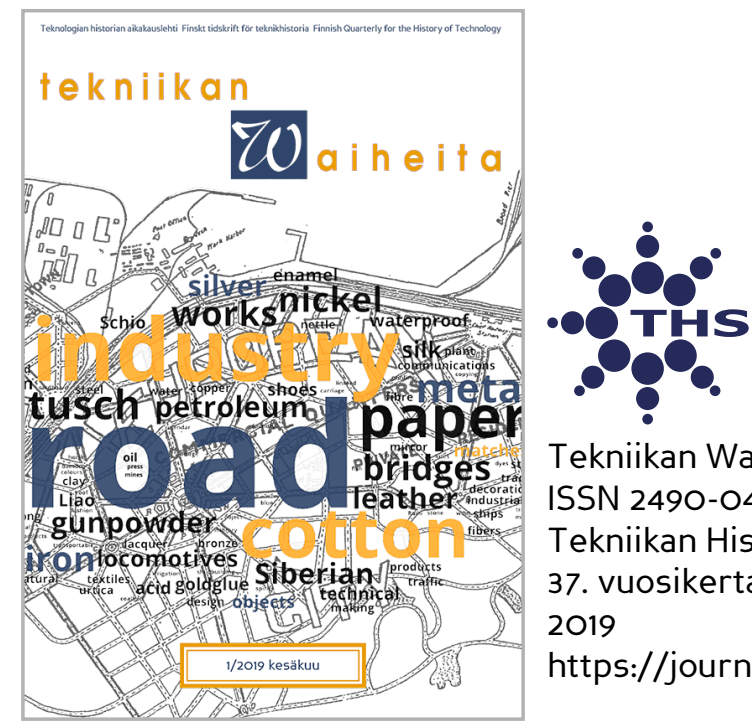

Tekniikan Waiheita

ISSN 2490-0443

Tekniikan Historian Seura ry.

37. vuosikerta:1

2019

https://journal.fi/tekniikanwaiheita

Konepajakulttuuri talteen - pelastusdokumentointia ja historian keruuta Hyvinkään lakkautettavalla konepajalla

Marina Bergström

To cite this article: Marina Bergström, "Konepajakulttuuri talteen: pelastusdokumentointia ja historian keruuta Hyvinkään lakkautettavalla konepajalla," Tekniikan Waiheita 37, no. 1 /2019): 41-57.

To link to this article: https://doi.org/10.33355/tw.83225 


\title{
Konepajakulttuuri talteen - pelastusdokumentointia ja historian keruuta Hyvinkään lakkautettavalla konepajalla
}

\author{
Marina Bergström
}

VR Hyvinkään konepajan toiminta ajettiin yllättäen alas vuosien 2017-2018 aikana. Suomen Rautatiemuseo pelastusdokumentoi konepajan toimintaa viimeiset vuodet. Konepajan ja sen työntekijöiden merkitys rautatiekaluston kunnossapidon osaajina käy ilmi dokumentointiaineistosta, vaikka kaikkia toimintoja ei saatukaan tallennettua. Konepajatyöntekijöiden aktiivinen osallistuminen hankkeeseen rikastutti aineistoa merkittävästi.

VR:n Hyvinkään konepajan historia alkaa vuodelta 1915 Rautatiehallituksen asettamasta komiteasta, joka lähti selvittämään uuteen keskuskonepajaan liittyviä kysymyksiä. Helsingin konepaja rautatieaseman vieressä oli käynyt ahtaaksi ja uudelle keskuskonepajalle piti löytää paikka. Erinäisten vaiheiden jälkeen konepajaa alettiin rakentaa Hyvinkäälle Sahanmäkeen vasta 1940-luvulla ja toiminta pääsi alkamaan kesällä 1949. Tällöin oli korvattavana myös sodassa menetetty Viipurin konepaja. Konepaja rakennettiin raskaan vetokaluston huoltoa varten ja siellä toimi aikanaan myös kattilapaja, VR:n viimeiset takomo ja valimo, sähkökonepaja, keskusvarasto, kiskohitsaamo, VR:n kirjapaino ynnä muuta. Hyvinkään konepajalla oli keskuskonepajana ja myöhemminkin suurimpana veturikonepajana valtakunnallisesti tärkeä rooli rautatiekaluston kunnossapidossa. Isona työnantajana konepajalla on ollut merkitystä myös paikallisesti Hyvinkäällä ja se on vaikuttanut kaupungin kehittymiseen. ${ }^{2}$

Tammikuussa 2017 varmistui, että VR aikoo lakkauttaa Hyvinkään konepajan, toisen jäljellä olevista konepajoistaan, kahden vuoden kuluessa siirtämällä toimintoja kunnossapidon muihin yksiköihin ja alihankkijoille. Toimintaa oli supistettu jo vuosia, ja vuonna 2017 konepajalla oli enää noin 200 työntekijää, osa heistä alihankkijoiden palkkalistoilla. Konepajalla tehtiin silti edelleen raskaan vetokaluston huollot, täyskorjaukset ja muutostyöt sekä vauriokorjaukset. Siellä korjattiin vetureita, sähkömoottorijunia ja matkustajavaunuja; huollettiin telit ja pyöräkerrat ja sen vastuulla oli junien sähkö- ja elektroniikkatuotanto.

Hyvinkään konepaja on osa kansallista teollista perintöämme. Konepaja on ollut merkittävä toimija VR:n historiassa ja sen toiminnot erikoistuneita muihin konepajoihin nähden. Hyvinkään konepaja on ollut myös tärkeä identiteettiä muokkaava tekijä paikallisille ja ammatillisille yhteisöille. Hyvinkäällä uutinen konepajan lakkauttamisesta aiheutti kysymyksiä ja huolta. Konepaja toimintoineen oli pelastusdokumentoitava.

Valtakunnallisena rautatieliikenteen erikoismuseona Suomen Rautatiemuseo tallentaa myös rautatiekaluston kunnossapitoon liittyvää toimintaa. Rautateihin liittyvä konepajateol-

\footnotetext{
${ }^{1}$ Kirjoittaja on Suomen Rautatiemuseon näyttelypäällikkö. Lisää kuvia VR Hyvinkään konepajan historiasta löytyy osoitteesta: www.finna.fi hakusanalla Suomen Rautatiemuseo.

${ }^{2}$ Lisää kaupungin ja konepajan suhteesta ja konepajan historiasta mm. Lahtinen 2017, ja Suomen Rautatiemuseon näyttely VR:n konepajat 13.12.2018-30.4.2020.

${ }^{3}$ Parhaina vuosina konepajalla oli työskennellyt yli 1200 henkilöä, alkujaan konepajaa oli suunniteltu jopa 3000 henkilön työpaikaksi. Ks. VR Hyvinkään konepaja 1949-1999, 2002 ja VR Hyvinkään konepaja 50 vuotta 1999, s. 17.
} 


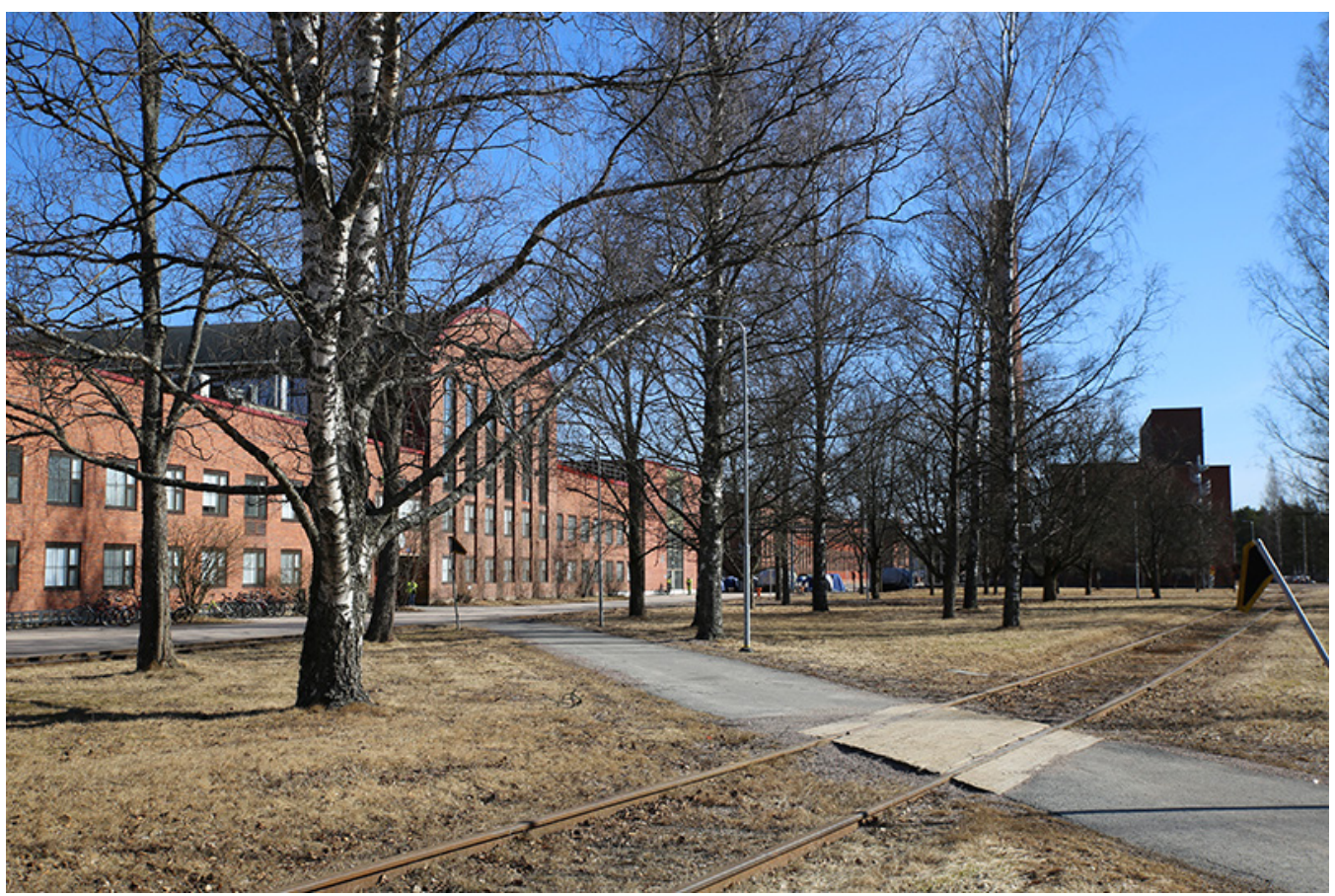

Hyvinkään konepajan päärakennus keväällä 2017. Katsauksen kaikki kuvat: Suomen Rautatiemuseo.

lisuus on määritelty Rautatiemuseon tallennusvastuualueeksi museoiden TAKO-yhteistyön ${ }^{4}$ tallennusjaossa. Museon kokoelmiin kuuluukin jo ennestään paljon aiheeseen liittyviä kuvia ja muita objekteja. Museo on lisäksi 2000-luvulla dokumentoinut VR:n kunnossapidon työtä - Ilmalan varikolla Sm-junien huoltoa ja Hyvinkään konepajalla Sm2-junien saneerauksia. Laajempia kunnossapidon dokumentoinnin hankkeita ei kuitenkaan vielä oltu tehty. Samalla, kun museolla suunniteltiin konepajan pelastusdokumentointiin ryhtymistä, otti VR:n kunnossapidon viestintä yhteyttä ja ehdotti dokumentointia.

VR ja konepajan johto suhtautuivat hankkeeseen myötämielisesti ja sallivat vapaan kuvaamisen sekä kohtuullisen työntekijöiden haastattelun työajalla. Kaikki kuvaaminen oli siis sallittua ja kuvat tarkastettiin vasta ennen käyttöä, jolloin niille joko annettiin julkaisulupa, karenssiaika tai niiden julkaisu ja tallennus kiellettiin. Konepajan johtaja nimesi yhteyshenkilöt eri vastuualueilta ja lisäksi yhden asiantuntijan opastamaan dokumentointiryhmää yleisissä kysymyksissä. Työntekijöiden kuvaaminen oli sallittua näiden luvalla, jonka hankkimista varten käytimme siihen muotoiltua lomaketta. Myös työntekijät suhtautuivat hankkeeseen positiivisesti ja kuvauslupien saaminen oli helppoa, kuten myös informaation saaminen työnteosta.

Yhteydenpito konepajalle sujui koko ajan hyvin huolimatta siitä, että dokumentointiprojektin aikana konepajan johtaja vaihtui kaksi kertaa ja myös kunnossapidon viestinnässä vaihtuivat ihmiset. Kuitenkin heihin ja myös muihin yhteyshenkilöihin saatiin luotua luottamukselliset suhteet ja kaikki olivat kiinnostuneita dokumentoinnista sekä tarjosivat apuaan.

\footnotetext{
${ }^{4}$ TAKO on Suomen museoiden tallennus- ja kokoelmayhteistyöverkosto www.tako.nba.fi.
} 
Dokumentointiryhmältä odotettiin turvallisuuskoulutuksen käyntiä ja turvavarusteiden käyttöä, mutta näiden reunaehtojen täytyttyä työryhmän jäsenet saivat liikkua vapaasti konepajan alueella. Suurimpaan osaan konepajan alasajoon liittyvistä aikatauluista ja suunnitelmista kuului salassapitovelvollisuus ja kaikkea ei meille edes kerrottu. Siksi aikataulun hahmottaminen oli välillä haasteellista. Toisaalta meille esiteltiin konepajaa hyvinkin avoimesti ja ehdotettiin tärkeitä ja merkittäviä dokumentointikohteita. Myös yhteyshenkilöille eri osastoilla annettiin hyvinkin vapaat kädet näyttää meille osastojensa toimintaa. Luontevaa kanssakäymistä varmasti edesauttoi, että museo oli konepajalla tuttu: muun muassa museon hallussa oleva liikennekelpoinen liikkuva kalusto kävi aika ajoin huollossa konepajalla. Lisäksi moni muisti yhteistyön parinkymmenen vuoden takaa konepajan 50-vuotisjuhlanäyttelyn merkeissä. Vaikka museotyö ja dokumentointikäytännöt saattoivat olla vieraita, museo itsessään miellettiin tutuksi ja tärkeäksi toimijaksi rautatieliikenteen tallentajana.

VR:n historia valtion virastona ja rautatieliikenteen monopolina loi konepajalle oman yksityisistä yrityksistä poikkeavan taustan. Valtakunnallisen ja valtiollisen toimijan tutkiminen antoi tähän pelastusdokumentointiin erityisen leiman, mutta sen asettaminen paikalliseen kontekstiin oli myös tärkeää, sillä Hyvinkäältä poistui yksi perinteisistä 'kolmesta suuresta' työnantajasta. ${ }^{5}$

Dokumentointia ohjasi näkemys siitä, että konepaja on merkittävä ja monipuolinen kokonaisuus sekä miljööltään että toiminnaltaan, sekä paikallisesti että valtakunnallisesti, mutta että emme aikataulullisesti ja sisällöllisesti pystyisi huomioimaan kaikkea tai tekemään kaiken kattavaa dokumentointia. Tiedostimme, että perinteinen rautateiden konepajatoiminta oli muuttumassa radikaalisti ja liikenneministeriön dokumentoinnin aikana ilmi tulleet aikeet rautatieliikenteen avaamisesta kilpailulle ja siihen liittyvistä yhtiöjärjestelyistä vaikuttaisivat myös kunnossapidon järjestämiseen ja kaluston omistajasuhteisiin. ${ }^{6}$ Pelastusdokumentoinnin vaikutukset siis olisivat suuremmat kuin vain Hyvinkään konepajan lakkautuksen taltioiminen.

\section{Nykydokumentointia pelastusdokumentointina}

Hankkeessa haluttiin dokumentoida ${ }^{7}$ konepajatyötä, konepajaa työpaikkana, työyhteisöä, työvälineitä ja -menetelmiä sekä myös teollista miljöötä. VR tilasi samoihin aikoihin rakennushistoriallisen selvityksen konepajasta ulkopuoliselta arkkitehtitoimistolta. Museota kiinnosti totta kai myös kalusto, jota konepajalla korjattiin. Mutta aikaa uhrattiin paljon laajempien ilmiöiden tavoittamiseen ja aineettoman kulttuuriperinnön tallettamiseen. Tavoitteena oli kiinnittää huomiota työtapoihin ja käytäntöihin sekä kunnossapidon tietojen ja taitojen hyödyntämiseen ja välittämiseen.

Dokumentoinnin lähestymistapa oli kansatieteellinen ja konepajan toimintoja tallennettiin ilmiöpohjaisen nykydokumentoinnin menetelmiä käyttäen. Dokumentointi eteni dokumentoitavan kohteen ehdoilla ja, ikävä kyllä, lakkautusaikataulun ohjaamana. Aikataulu toi kiireen, jonka vuoksi pystyimme olemaan yhdessä kohteessa korkeintaan muutamia päiviä.

\footnotetext{
${ }^{5}$ Hyvinkään 'kolme suurta', joihin lähes jokaisella paikkakuntalaisella on ollut jokin kosketus, olivat Villatehdas, Kone ja VR:n konepaja. Lue lisää Lahtinen 2017.

${ }^{6}$ 5.6.2018 LVM tiedote: https://www.Ivm.fi/-/rautateiden-henkiloliikenteen-kilpailun-avaaminen-etenee-yhtiojarjestelyilla-976098.

${ }^{7}$ Lue lisää teollisuuden dokumentoinnista mm. Industriedokumentation 2014.
} 
Toiveemme on, että pystymme vielä käymään kunnossapidon muissa kohteissa dokumentoimassa siirrettyjen toimintojen uusia tiloja sekä työtapoja ja samalla uutta normaalitilannetta kunnossapitotoiminnassa.

Nykydokumentointi menetelmänä auttaa jättämään jälkipolville monipuolisen kuvan meneillään olevasta murrosvaiheesta. Menetelmä tukee kokonaisvaltaista dokumentointia, jolla erilaiset näkökulmat, mielipiteet ja yksilöiden kokemukset tallennetaan virallisen organisaation näkökulman rinnalla. Myöhemmin tehtävä keruu yksipuolistaisi näkökulmaa, joten haastattelut on tehtävä dokumentoinnin yhteydessä.

Dokumentoinnin luonne pelastusdokumentointina ${ }^{8}$ tulee ilmi aineistossa. Töitä oli jo siirretty muualle, monen oman työn jatko oli epävarmaa, aikataulut ja toimintatavat eivät olleet enää normaaleja. Tämä huomioitiin jo dokumentointia suunniteltaessa. Siksi myös informanttien omaan taustaan ja tulevaisuuteen kiinnitettiin huomiota kenttätyötilanteissa. Lisäksi pyrittiin hahmottamaan, mikä on ollut viimeaikainen muutos työskentelyssä, ja jäljittämään, mitkä muutokset ja toimintatavat ovat lakkautuksen aiheuttamia.

Dokumentointi oli havainnoivaa, kohteita seurattiin aktiivisesti ja työntekijöitä pyydettiin selittämään työvaiheita ja työnsä tarkoitusta. Työntekijöiltä kyseltiin myös koulutustaustasta, aiemmista työtehtävistä, työyhteisöstä ja tunnelmista lakkautuksen kynnyksellä. Myös viimevuosien muutosta työssä ja työpaikalla pyydettiin kuvailemaan.

Dokumentointi oli visuaalista. Dokumentointikerroilla kuvattiin parhaimmillaan viidellä kameralla, joista osalla liikkuvaa kuvaa. Kamera kohdistettiin työtehtävän ja työntekijän lisäksi työympäristöön ja miljööseen. Videokuvauksen tarkoituksena oli liikkuvan kuvan tallentamisen lisäksi tallentaa myös ääntä, sillä äänen tallentamiseen erikseen ei museolla ollut käytössä osaamista tai laitteita. Satunnaisesti dokumentoinnin yhteydessä otettiin talteen myös siihen liittyvää arkistomateriaalia. Esinekeruu suoritettiin pääasiassa erikseen ja hyvin pienimuotoisena. Esinekeruu painottui konepajan ja työyhteisön historiaan. Erityisesti museota kiinnosti rautatiekalustoa varten tehdyt tai tuunatut työkalut ja konepajalla itse valmistetut työvälineet, joita lopulta löytyi enää hyvin niukasti. Työpisteiltä saatiin myös työntekijöiden ottamia kuvia, jotka saattoivat olla miltä ajalta tahansa ja liittyä niin työhön kuin työyhteisöönkin.

Dokumentointikäyntien yhteydessä tehtyjä henkilöhaastatteluja varten luotiin löyhä runko, mutta käytäntö saneli yleensä haastattelun kulun. Informanteilta yritettiin saada samat perustiedot, joskin toiset olivat avoimempia ja laveasanaisempia kuin toiset. Osa informanteista pyydettiin erikseen vielä syvällisempään haastatteluun, jossa käytiin läpi henkilön työhistoriaa konepajalla ja konepajan elämää sekä muutoksia. Osa haastatteluista painottui selvästi tiettyyn teemaan kuten esimerkiksi oppilaskouluaikaan tai konepajalaisten yhteisiin harrastuksiin.

Haastetta dokumentointiin toivat dokumentoitavien kohteiden koon moninaisuus: välillä edessä oli kokonainen veturi, jota nostettiin jättimäisillä nostureilla jopa toisten veturien yli, välillä pieniä laakereita korjattiin pinsettejä apuna käyttäen. Välillä kyseessä oli viisi viikkoa kestävä veturin täysremontti, joskus taas muutamassa kymmenessä minuutissa suoritettu huomiovalon vaihto. Paljolti dokumentointiryhmän koosta johtuva joustavuus auttoi kohtaamaan erityyppiset kohteet ja mukautumaan niiden asettamiin dokumentointivaatimuksiin.

\footnotetext{
${ }^{8}$ Pelastusdokumentoinnin parhaat käytännöt: https://www.museoliitto.fi/index.php?k=12969
} 
Rahoitusta hankkeelle on saatu useilta rahastoilta ja säätiöltä. ${ }^{9}$ Näin hankkeelle voitiin palkata projektitutkija. Museo päätti resursoida hankkeeseen kunnolla ja museon henkilökunnasta dokumentointiin osallistui 4 henkilöä vaihtelevasti omien työtehtäviensä ohella. Kenttätyöpäiviä kertyi loppujen lopuksi 27.

\section{Työnjako}

Dokumentointityöryhmän työnjako muodostui nopeasti kunkin jäsenen vahvuuksien mukaan. Kenttätöihin osallistuivat museon henkilökunnasta kokoelmapäällikkö, näyttelypäällikkö ja kaksi amanuenssia. Heistä yksi havainnoi ja kolme kuvasi. Projektitutkija havainnoi, haastatteli dokumentointikäynneillä informantteja, kirjoitti dokumentointipäiväkirjat ja seuloi sekä luetteloi kertyneen materiaalin käyntien jälkeen.

Kun aihetta myöhemmin laajennettiin konepajan ja konepajalaisten historia tallentamiseen, haastatteli projektitutkija informantit ja keräsi heiltä vanhoja valokuvia sekä esimerkiksi tietoa viraabelitöistä. Hankkeeseen palkattiin myös videokuvaaja kuvaamaan ja koostamaan muutamia muun muassa näyttelykäyttöön tarkoitettuja videoita eräistä mielenkiintoisista toiminnoista.

Dokumentoijat toimivat useimmiten pareina, joissa havainnoija/haastattelija ja kuvaaja seurasivat yhdessä yhtä työvaihetta tai työntekijää. Kaikki dokumentoijat eivät osallistuneen kaikkiin kenttätyöpäiviin, vaan ryhmän kokoonpano vaihteli ryhmäläisten muiden työtehtävien takia.

\section{Dokumentointikohteet ja -käynnit}

Ensimmäiset palaverit konepajalla käytiin yhteistyössä konepajan johdon ja VR:n kunnossapidon viestinnän kanssa. Tällöin sovittiin dokumentoinnin ehdoista ja tutustuttiin konepajaan. Lakkautusaikataulu antoi raamit dokumentoinnin suunnittelulle ja kierros konepajalla antoi kuvan monitahoisesta historiallisia kerrostumia runsaasti sisältävästä laajasta kokonaisuudesta. Kierroksella kävi selväksi, että kaikkea konepajan toimintaa on mahdotonta kattavasti tallentaa, ja että hyvin paljon mielenkiintoista toimintaa on jo vuosien kuluessa hiljalleen ajettu alas. Kierros osoitti kuitenkin myös sen, että konepaja on ollut viimeiseen asti kehittyvä ja moderni laitos, viimeisimpiä uudistuksia oli tehty aivan viime vuosina.

Konepajan dokumentoinnin alkaessa konepajan toiminnot oli jaettu kolmeen isompaan osa-alueeseen: kalustotuotantoon, mekaanisiin vaihto-osiin sekä sähköön ja elektroniikkaan, joiden alla oli eri osastoja ja toimintoja. Konepaja-alueella toimi dokumentoinnin alkaessa myös VR Trackin varasto, mutta se ei kuulunut dokumentoinnin piiriin, koska kyseessä ei ollut VR:n kunnossapidon alainen toiminta. Myöskään kunnossapidon varaston toimintaa ei varsinaisesti dokumentoitu, sillä aika ei tähän riittänyt.

Työ eteni käytännössä niin, että alussa dokumentointiin aikajärjestyksessä poistuvia toimintoja ja suurempia kokonaisuuksia. Loppupuolella hanketta käytiin tallentamassa pienempiä ja aiempaa dokumentointia täydentäviä kohteita. Aivan kaikkia kohteita ja toimintoja ei

\footnotetext{
9 Jenny ja Antti Wihurin rahasto, Teollisen kulttuurin tutkimusrahasto / Emil Aaltosen säätiö, Suomen Kulttuurirahaston Uudenmaan rahasto, Museovirasto ja Raideammattilaisten osasto 2 JHL ry Hyvinkää.
} 


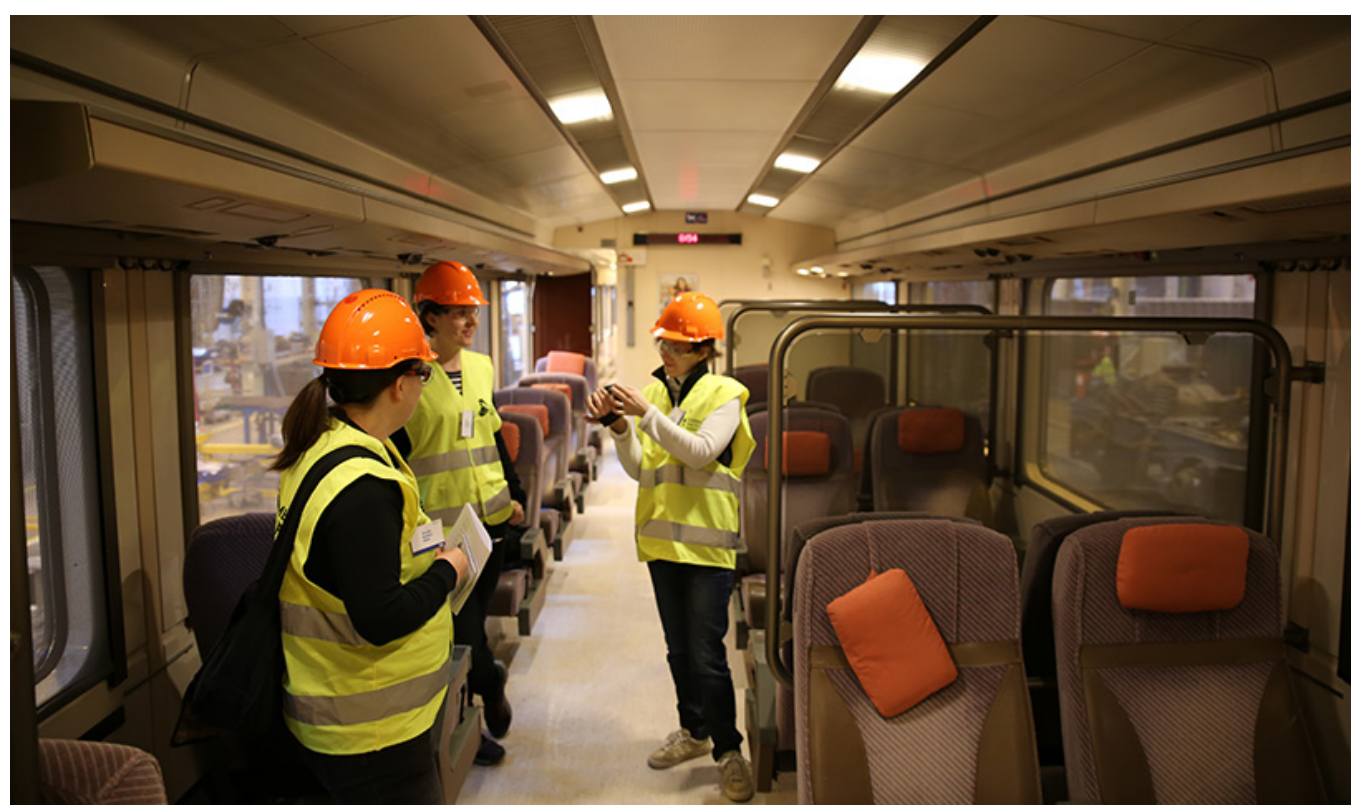

Osa dokumentointiryhmää ensimmäisenä kenttätyöpäivänä neuvottelemassa seuraavasta siirrosta.

saatu talteen aikataulujen tai muiden haasteiden takia. Hankkeessa dokumentoitiin myös muutamia yhteistilaisuuksia ja muuton valmisteluja. Aivan lopuksi seurattiin vielä viimeinen dieselveturin huoltoa pääpiirteissään.

Vaikka dokumentointikäynnit pyrittiin suunnittelemaan hyvin, ei koskaan voinut olla täysin varma mitä eteen tulee. Toisinaan suunniteltu dokumentoitava tilanne oli siirtynyt jonkin viivästyksen tai jonkin kiireellisemmän korjauksen takia myöhemmäksi tai tehty jo ennen dokumentoijien saapumista aikataulujen muututtua korjaustyössä. Tosinaan jopa suunnittelukäynneillä saattoi ilmetä, että lähistöllä käynnissä oleva toiminto olikin nyt työ, jota tehtiin konepajalla viimeistä kertaa - tällöin tilanteeseen tartuttiin aikailematta. Laaja dokumentointiryhmä antoi mahdollisuuden joustoihin kenttätyöpäivien aikana.

Ensimmäinen dokumentointikäynti toimi myös harjoitteluna, sillä aikaisemmat kunnossapidon dokumentoinnit ovat olleet huomattavasti pienimuotoisempia tai rajatumpia ja tapahtuneet niin sanotusti normaalioloissa. Dokumentointi aloitettiin kaukoliikenteen matkustajavaunujen huollosta, vaunujen korjaus oli siirtymässä Ilmalan varikolle Helsinkiin huhtikuussa 2017. Tässä yhteydessä dokumentoitiin myös muuttoa kaikkein selkeimmin.

Dokumentoinnin haasteista saatiin kokemus heti alussa, kun huomattiin joidenkin korjaustoimenpiteiden pienimuotoisuus ja näkymättömyys. Vaunussa tehtiin lähinnä sähkötöitä sähkökaapissa, joten niiden kuvaaminen oli hankalaa. Lisäksi samassa yhteydessä huomattiin kokonaisuuden tallentamisen hankaluus, kun esimerkiksi vaunun takalyhdyn korjaus tapahtui aivan eri paikassa, eri aikaan ja eri ihmisten toimesta kuin mitä itse vaunun huolto. Näin saimme talletettua vain valon vaihdon, emme koko prosessia.

Toinen hankaluus, joka ilmeni heti aluksi ja joka vaivasi useampaa dokumentointikertaa, oli tapahtumien samanaikaisuus ja toisaalta erirytmisyys. Jos tarkoitus oli dokumentoida päivän aikana 4-6 eri työvaihetta 2 dokumentointiparin voimin, saattoivat nämä työt alkaa eri 


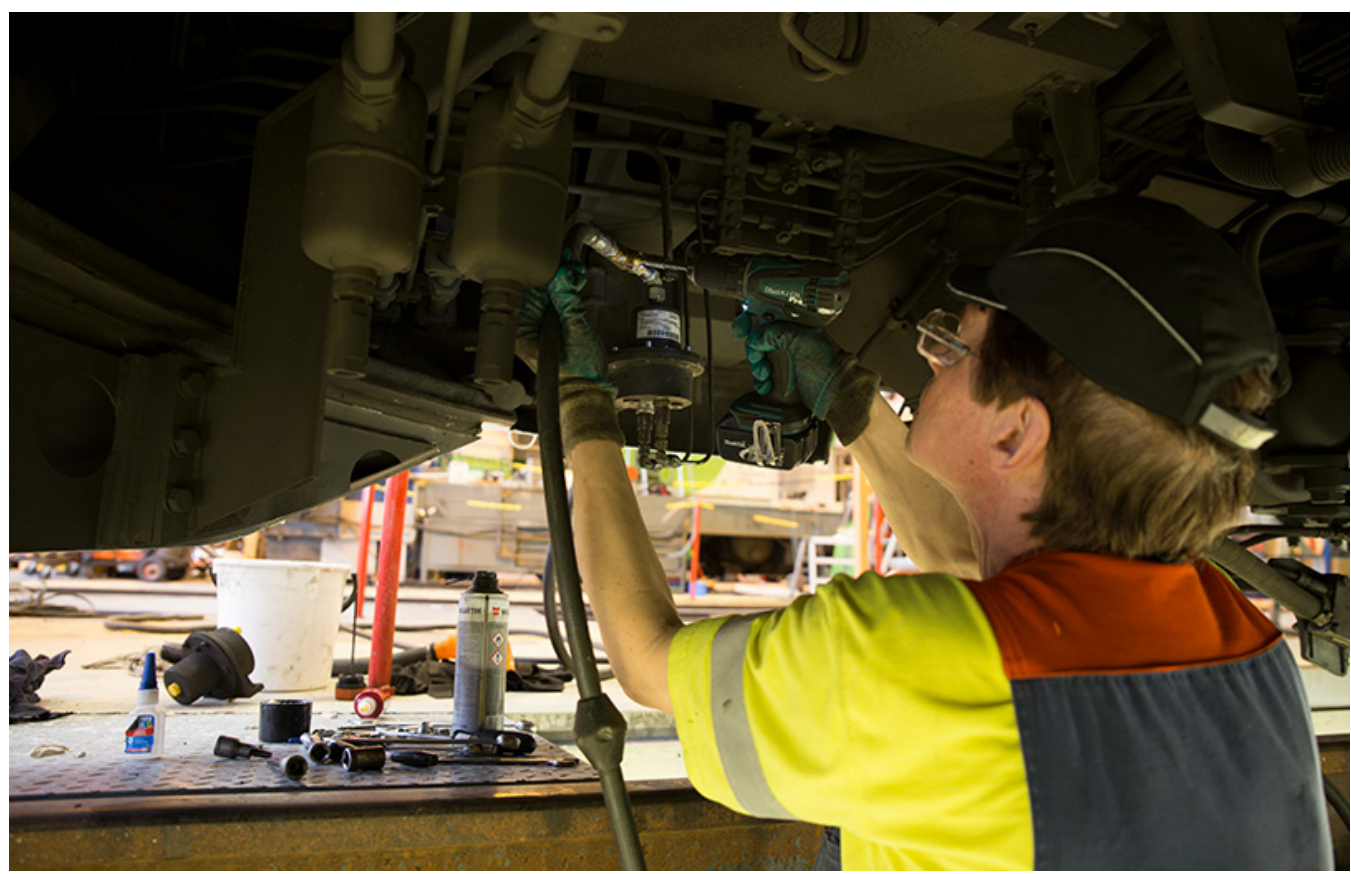

Laipanvoitelupumpun ilmauksen helpottamiseen on kehitetty itse työkalu.

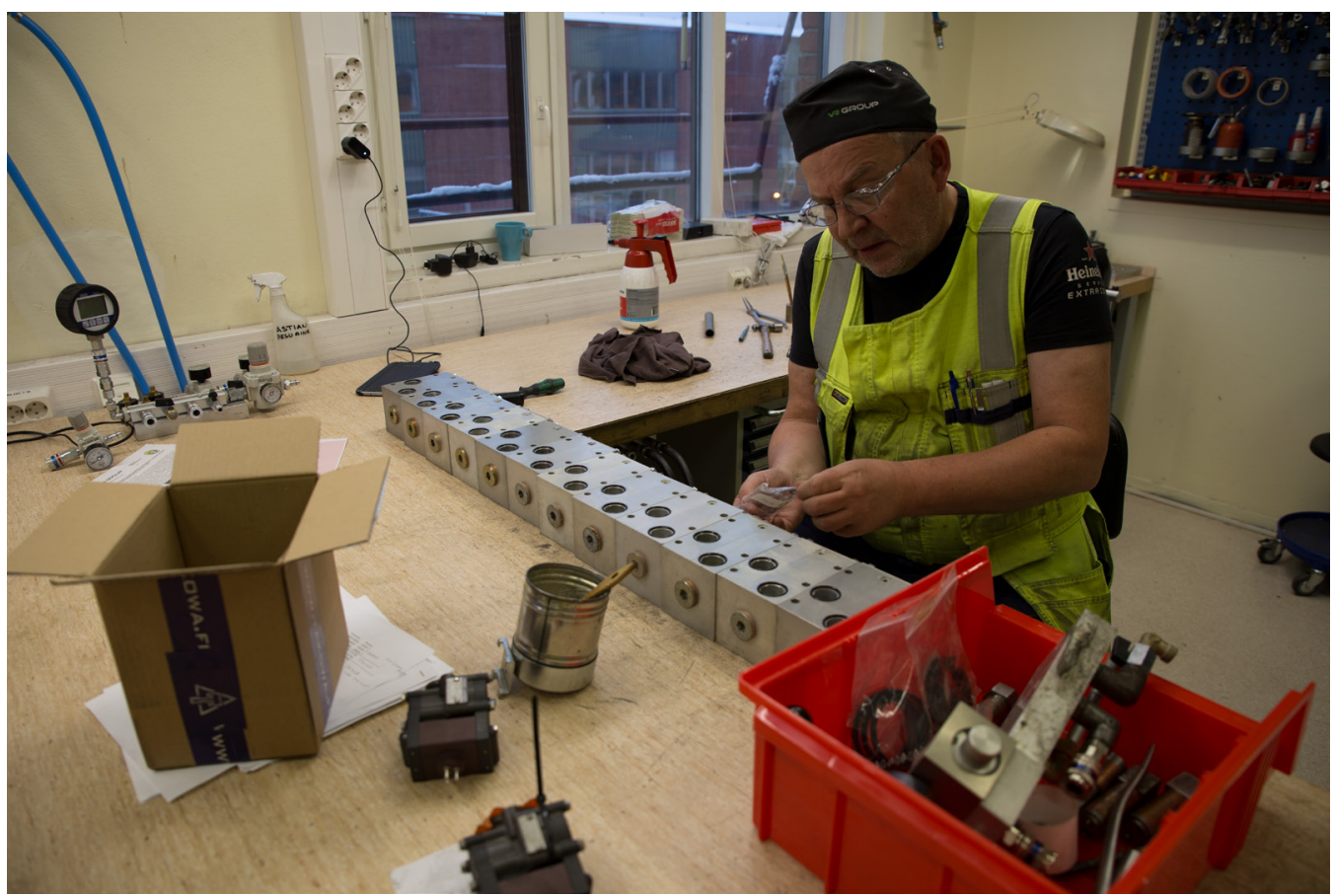

Sähkö- ja elektroniikkakorjaamon dokumentoinnissa kuvattavana oli pienikokoisia korjaustoimenpiteitä, kuten hätäjarruventtiileitä. 
aikaan, mutta niissä saattoi olla pitkiäkin taukoja ja välillä ne tapahtuivat lomittain tai päällekkäin. Tilanteista ei saanut tietoa juurikaan etukäteen, joten alituinen valppaus oli tarpeen.

Vaunuhuollon dokumentoinnin yhteydessä törmäsimme yllättäen myös sähkömoottorijunien ovien huoltotilanteeseen, joka saatiin talletettua suunnitelman ulkopuolelta. Tätä työtä ei tehty enää myöhemmin, kun dokumentoimme itse junan huoltoa. Työ tapahtui eri paikassa kuin muu Sm-huolto, joten emme sitä olisi ilman sattumaa löytäneetkään. Tapahtuma auttoi meitä ymmärtämään konepajan toimintaa ja pysymään tarkkoina sekä kyselemään enemmän.

Sähkömoottorijunien (Sm4) määräaikaisen VIS2-huollon dokumentoinnin yhteydessä dokumentoimme myös niitä ratkaisuja ja rakenteita, joita näiden niin sanottujen kaupunkijunien huoltoa varten oli kehitelty ja rakennettu. Kaupunkijunan huollon dokumentointiin olimme varanneet muutaman päivän, mutta koska esimerkiksi mielenkiintoinen välikytkimen ja palkeiden vaihto osui viikonlopulle, emme pystyneet tallentamaan sitä.

Kolmas dokumentointikohde oli jälleen osoitus tiettyjen toimenpiteiden ajankohtien ennakoimattomuudesta ja aikataulujen yhteensovittamisesta. Tiesimme, että kesäkuun alussa jonain päivänä Dr14 veturi on valmiina laskettavaksi teleilleen. Veturin nosto-operaatio on näyttävä tapahtuma ja museon kokoelmissa on useita kuvia eri ajoilta ja eri vetureista nostettuna ylös samassa hallissa, joten halusimme tallentaa myös tämän, yhden viimeisistä. Olimme pyytäneet, että meille ilmoitettaisiin, milloin lasku tapahtuu. Saimme soiton 40 minuutin varoitusajalla ja pääsimme onneksi lähtemään muutaman kameran ja videokameran kanssa paikalle. Itse operaatio oli lyhyt.

Välillä kenttätyöpäivien välillä oli pitkiäkin taukoja johtuen osaksi dokumentointiryhmäläisten muista töistä osaksi konepajan työ- ja siirtoaikatauluista. Joihinkin kohteisiin pystyimme silti varaamaan parikin kenttätyöpäivää, toisissa pystyimme suunnittelemaan varsinaista dokumentointikäyntiä etukäteistutustumiskäynnillä, mutta aina tämäkään ei ollut mahdollista.

Toukokuussa 2018 kävimme kuvaamassa videokuvaajan kanssa lähinnä pyöräkertoihin liittyviä töitä useampana päivänä. Teemat oli valittu erityisesti näyttelyn videotuotantoa varten, mutta näin saimme talletettua erilaisen kokonaisuuden, jossa seurattiin yhden työpisteen sijaan yhden sivuvirran tapahtumia.

Erityisdokumentointi suoritettiin 12.10.2018, kun Rautatiemuseo osallistui Suomen museoiden yhteiseen TAKO-yhteistyön organisoimaan Onni museoon -tallennustempaukseen. ${ }^{10}$ Kohteeksi valittiin koneistusosaston perjantaipulloarvonta, arvontavälineet ja jo vuodesta 1973 pidetty tilasto arvonnoista. Museon työntekijät katsoivat perjantaipulloarvonnan olevan sopiva osoitus suomalaisesta onnellisuudesta ja sen kääntöpuolista. Perjantaipulloarvonta juhlistaa odotetun viikonlopun alkamista, mutta pulloja voidaan arpoa vain hyvässä työyhteisössä. Arpaonni ei kuitenkaan aina jakaudu tasaisesti, ja konepajallakin on ollut osoituksia onnen kääntöpuolen ja alkoholin liitosta. Koneistusosaston arvontavälineistö valikoitui dokumentointiin sen viimeistellyn ulkoasun ja pitkäaikaisen tilastoinnin takia.

Viimeisenä, aivan vuoden 2018 lopulla, kun konepajaa jo tyhjennettiin vauhdilla ja koneita myytiin pois, dokumentoimme viimeistä konepajalla korjattavaa Dr14-veturia ja sen huoltoa. Vaikka nytkään emme saaneet täydellistä kuvaa veturihuollosta, saimme kuitenkin talletettua huollon pääpiirteet ja erilaisia töitä matkan varrelta. Erityisesti kiinnitimme huomiota työporukan toimintaan ja aamu- ja iltavuorolaisten työnjakoon.

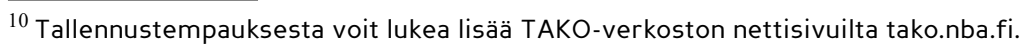




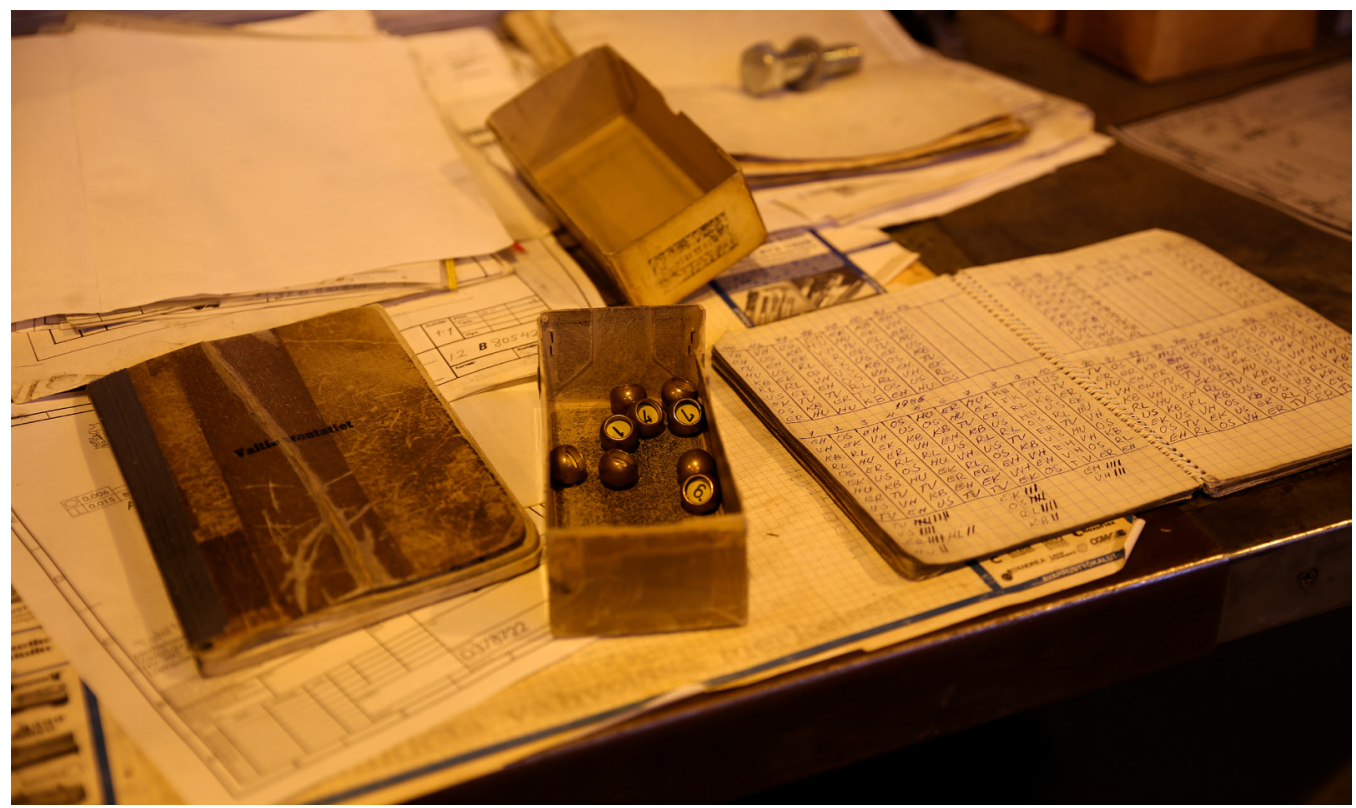

Onnen tallennukseen valitut arvontavälineet ja tilastokirjat.

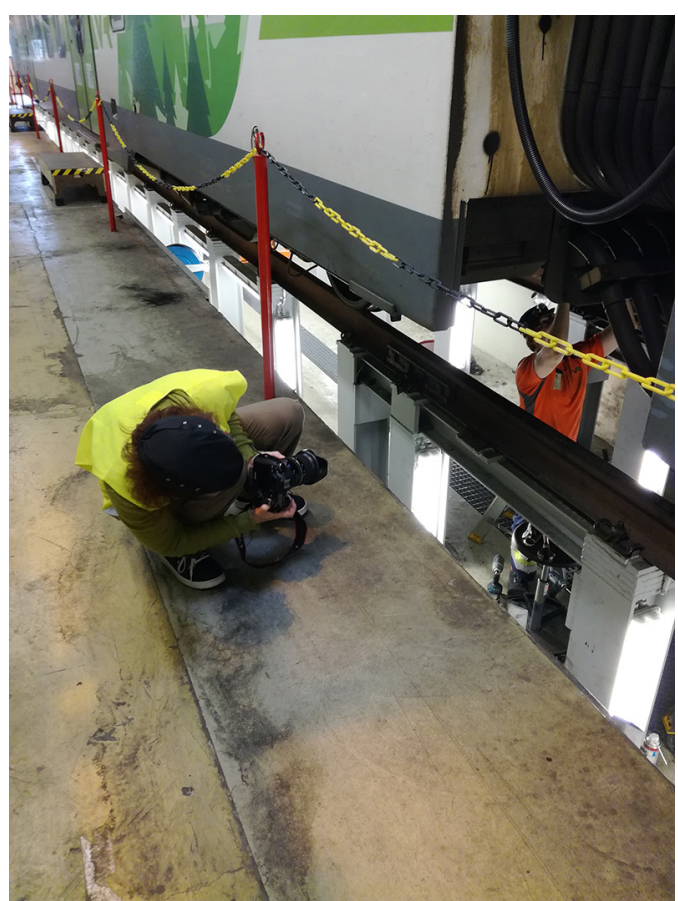

Välillä kunnon kuvakulman löytäminen vaati dokumentoijaltakin joustoa.

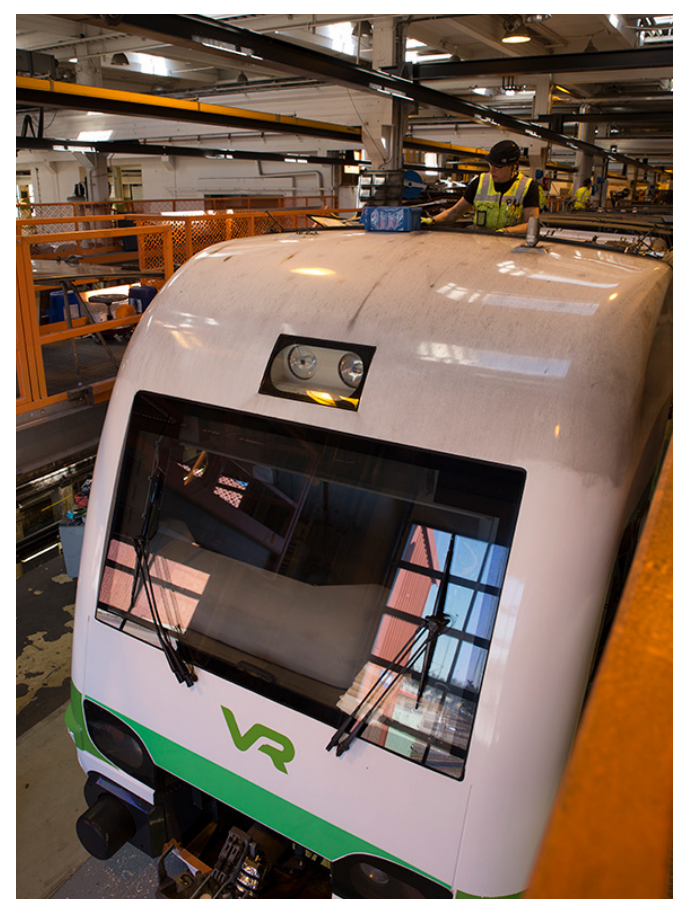

Sm4-junan korjausta, junan ympärillä näkyvät nimenomaan tämän tyypin korjaamiseen rakennetut telineet. 


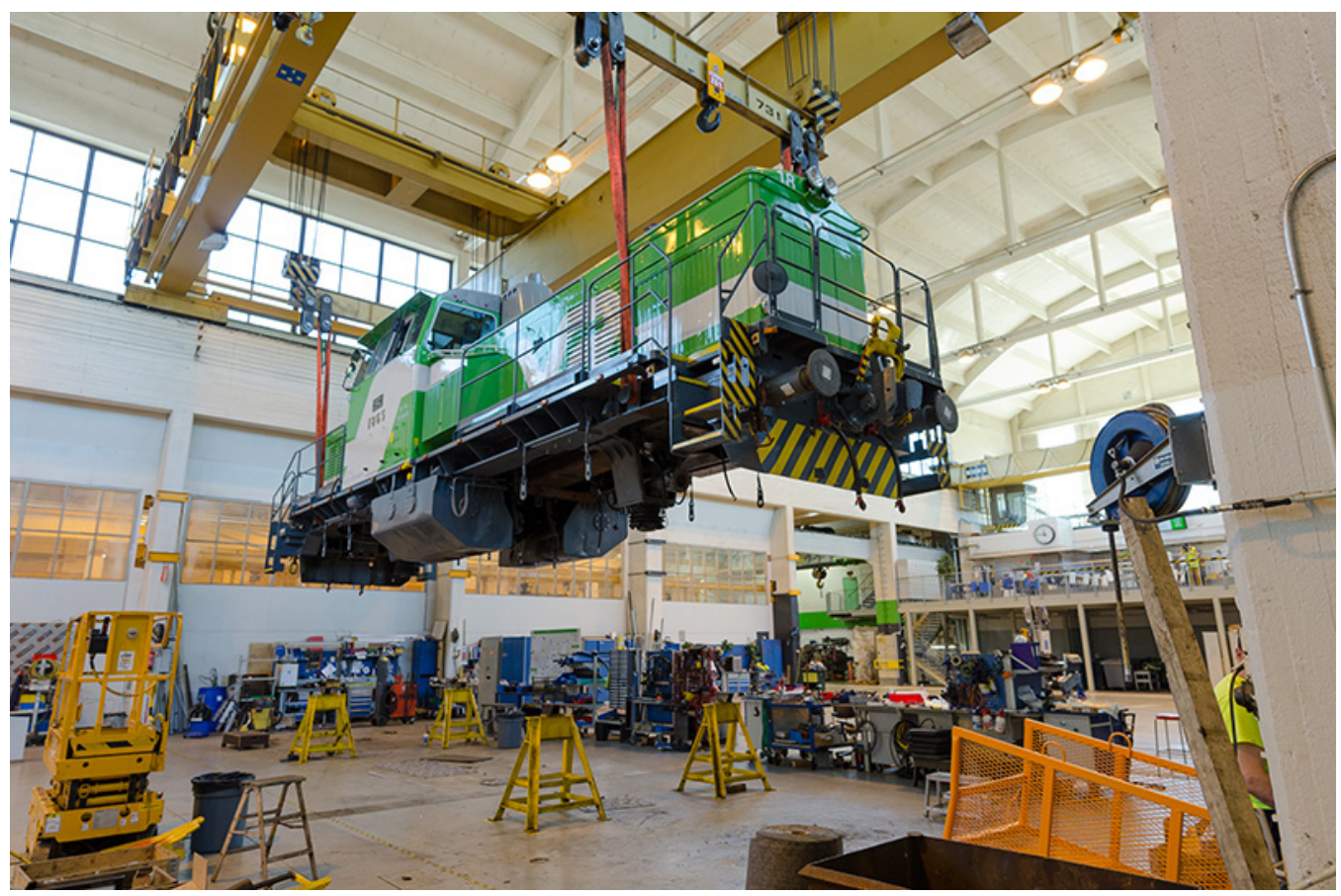

Odotettu kuvaustapahtuma toteutui, kun veturia viimein oltiin laskemassa teleilleen.

\section{Rakennukset}

Konepaja-alueella on useita rakennuksia, joista monien käyttötarkoitus on muuttunut. Keskeiset dokumentoinnin aikaiset konepajatoiminnot sijoittuivat kahteen suurimmista rakennuksista. Kävimme kuvaamassa myös muutamissa muissa rakennuksissa, mutta useimmat varastorakennuksina nykyään toimivat rakennukset jäivät dokumentoinnin ulkopuolelle.

Konepajan päärakennuksessa olivat muun muassa veturi-, vaunu- ja sähköjunakorjaamot, pikakorjaamo, teliosasto sekä pyöräkertaosasto ja osa moottoriosastoa. Päärakennuksessa sijaitsivat myös toimisto- ja koulutustilat, ruokala, arkisto sekä työkaluvarasto. Lisäksi oli pienempiä tiloja ja toimintoja.

Kattilapajan nimellä edelleen kulkevassa rakennuksessa sijaitsivat osa moottoriosastoa, koneistus ja sähkö-elektroniikka. Rakennuksessa oli myös jo toimintansa lopettanut metallilaboratorio.

Konepajan rakennuksia yhdistää tunneli, jonka varrella on muun muassa saunatiloja. Takomon nimellä kulkeva rakennus toimii nykyään varastona. Voimalakaan ei ole sen alkuperäisessä käytössä. 

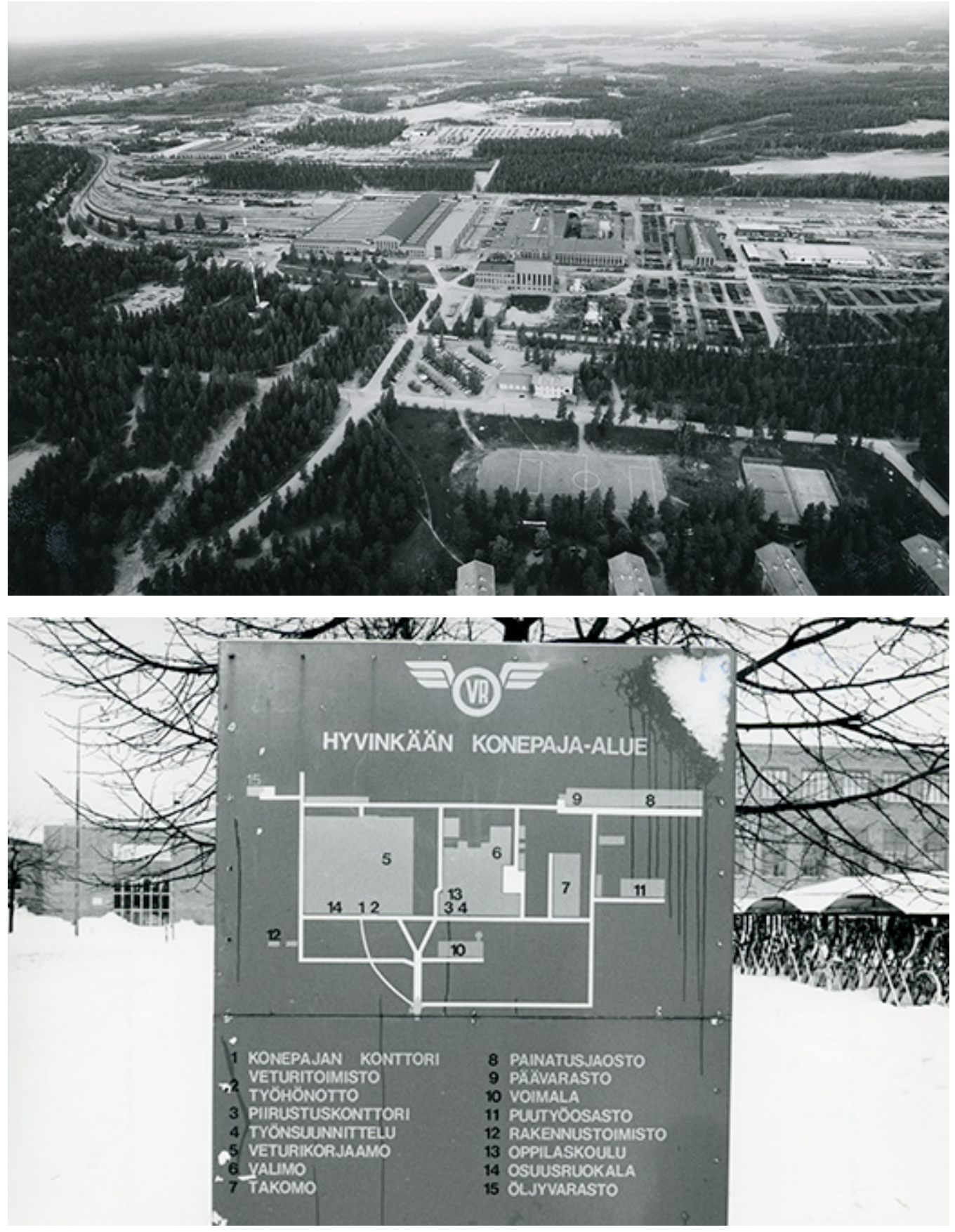

VR Hyvinkään konepaja 1980-luvun alussa. 


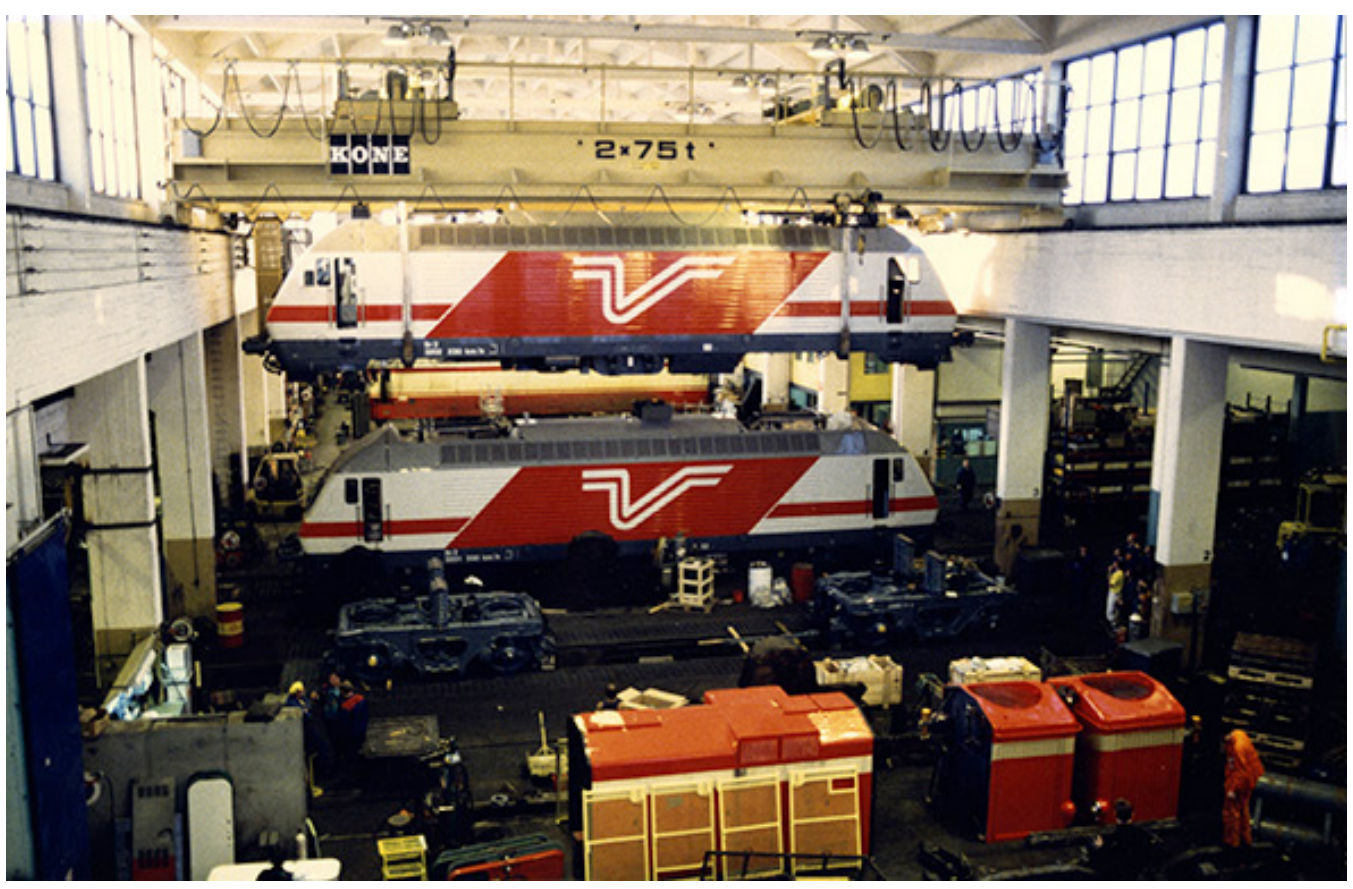

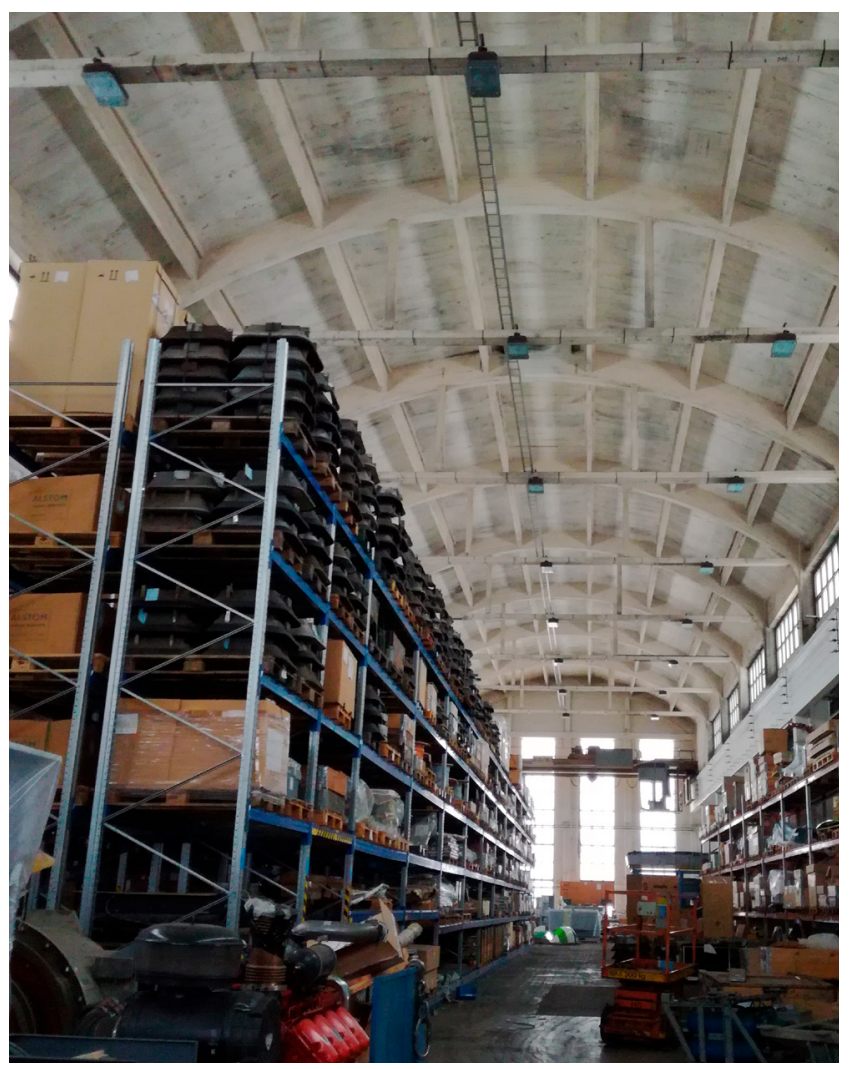

Näkymä nostohallista.

Entisen takomon korkean katon alla on ollut jo pitkään varaosavarasto. 


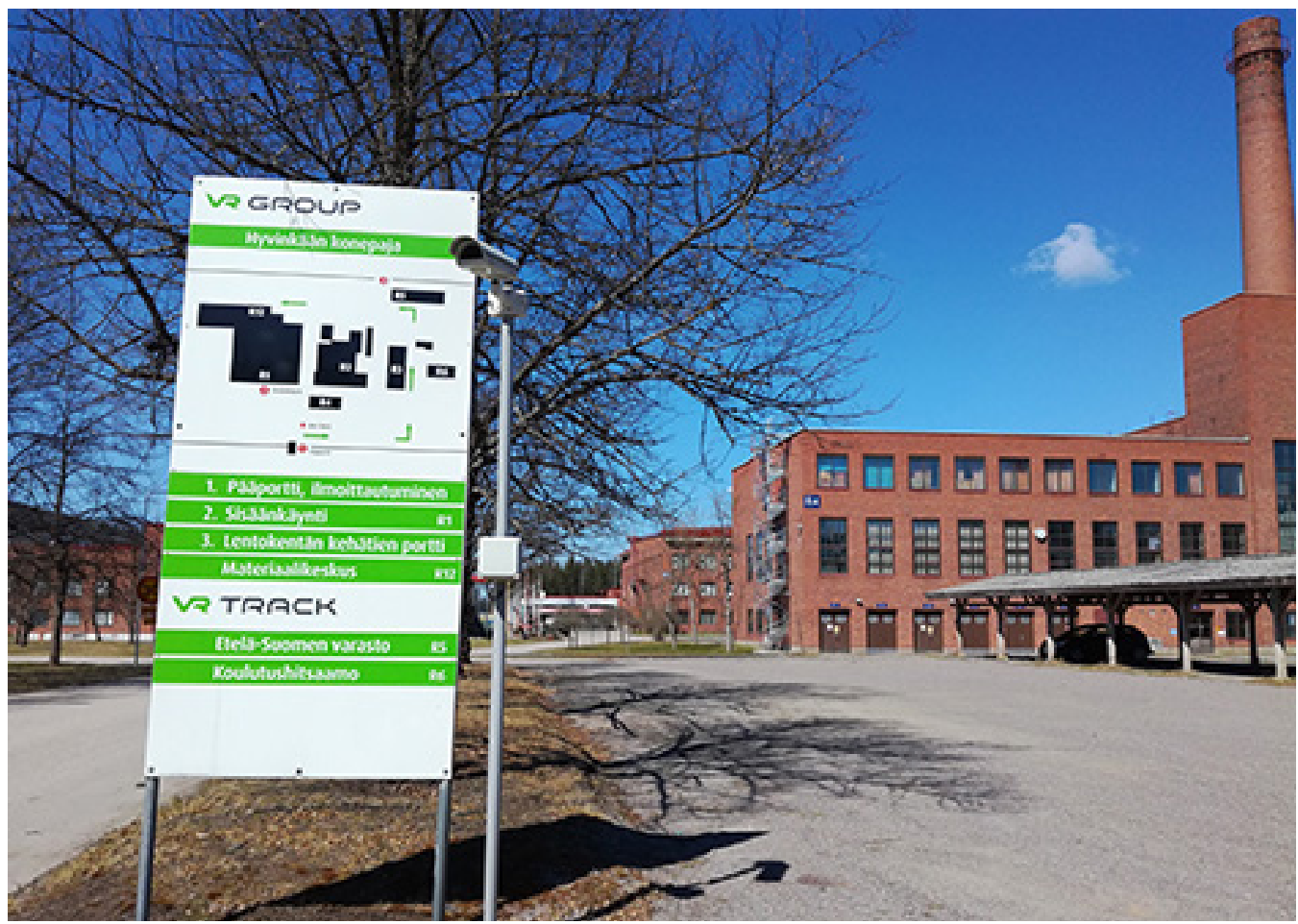

Hyvinkään konepaja vuonna 2017.

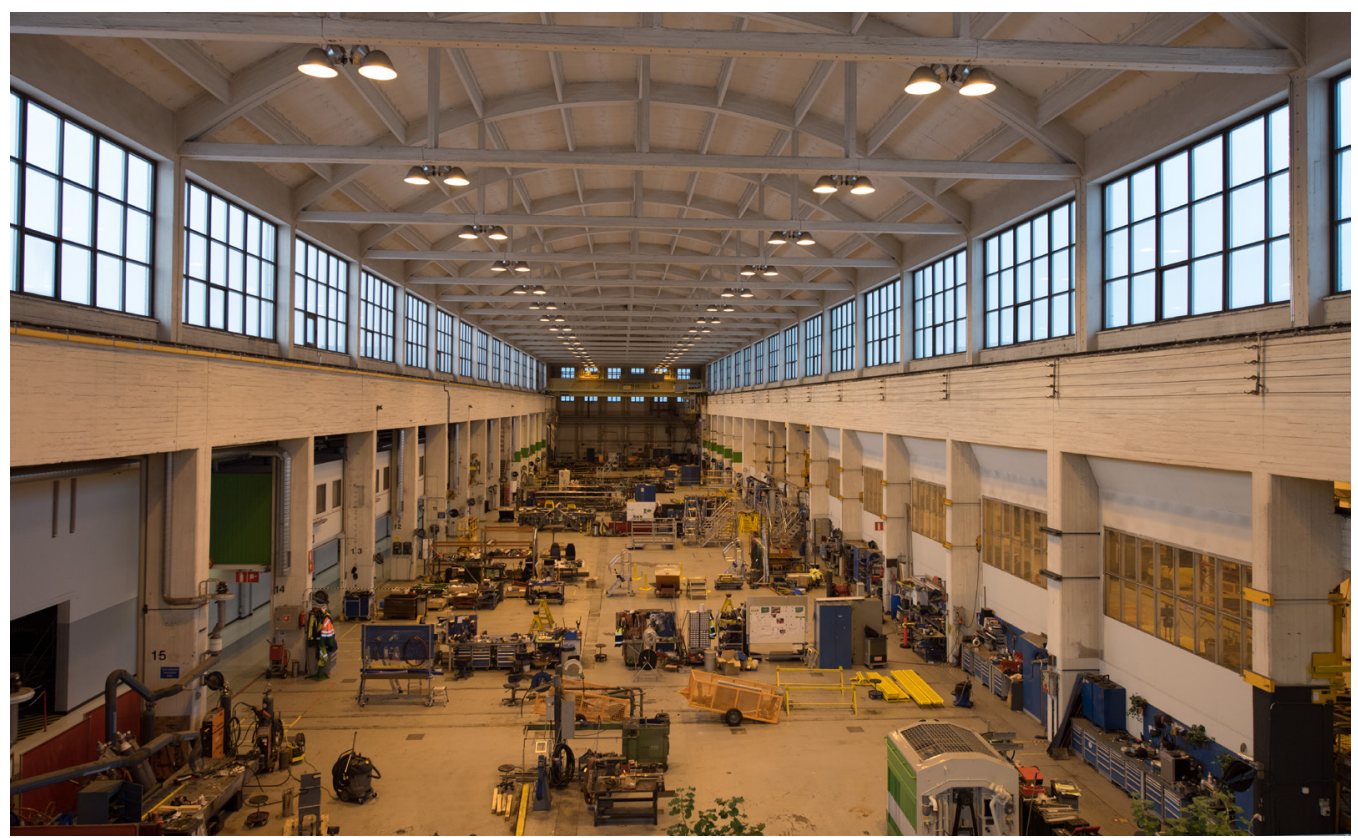

Konepajan veturihalli hetkellisesti tyhjänä viimeisien korjattavien dieselvetureiden välillä alkuvuodesta 2018. 


\section{Informantit}

Konepajan työntekijät, sekä VR:n palkkalistoilla olevat että alihankkijoiden henkilöstö, suhtautuivat pääsääntöisesti positiivisesti dokumentointiin. Osa töistä oli organisoitu niin, että tekijöinä oli pelkästään alihankkijan henkilöstöä, osassa työtiimeistä taas saattoi olla sekä VR:n että alihankkijan työntekijöitä. Vaikka dokumentointi kohdistui pääasiassa VR:n konepajatyöntekijöihin, lopulta mukana oli myös muutamia alihankkijoiden työntekijöitä.

Informantit olivat erilaisista taustoista kotoisin ja työurat konepajalla vaihtelivat muutamasta kuukaudesta yli neljäänkymmeneenviiteen vuoteen. Toiset olivat tehneet samaa työtä pitkään, toiset vaihdelleet osastolta toiselle. Eräiden perheenjäseniä, esimerkiksi vanhempia, oli myös ollut konepajalla töissä. Monilla perspektiivi konepajan muutokseen saattoi olla hyvinkin pitkä ja laaja. Haastatteluissa ja kenttätyöpäivien keskusteluissa tuli monesti selkeästi ilmi työn muutos sekä viimeisten vuosien aikana kiihtynyt muutostahti.

Toisissa tallennuskohteissa oli useampia informantteja tai jopa koko kyseinen työporukka, toisissa vain yksi tai muutama. Osa heistä taustoitti omatoimisesti kyseessä olevaa työkohdetta ja liitti sen suurempaan kokonaisuuteen sekä konepajalla että yleensä junaliikenteessä ja sen turvallisuudessa. Näin informanttien käsitykset oman työnsä merkityksestä ja sijoittumisesta suhteessa muihin junaliikenteen töihin tulivat samalla ilmi.

Informantteja pyrittiin osallistamaan dokumentointiin ja esinetallennukseen eri tavoin: kyselylomakkeella, henkilökuntainfossa ja dokumentointitilanteissa. Kukaan ei täyttänyt lomaketta. Vain muutama sellainen henkilö, joita emme olleet vielä varsinaisesti tavanneet dokumentoinnin yhteydessä, tuli konepajakäyntiemme yhteydessä ehdottamaan dokumentoitavaa kohdetta. Sen sijaan monet dokumentointikäynneillä tutuksi tulleet henkilöt tulivat myöhemminkin vinkkaamaan hyvistä dokumentointikohteista, esittelemään toisia henkilöitä haastateltaviksi tai kertomaan lisätietoja meitä aiemmin askarruttaneesta kysymyksestä.

\section{Kohteen taustat ja kansalaisten kiinnostus - laajeneva tutkimustyö}

Monet Hyvinkään konepajarakennukset ovat valmistuneet 1940- ja 1950-luvuilla. Tiloista osan käyttötarkoitus on pysynyt lähes samana, mutta suurimmassa osassa on tapahtunut muutoksia, ja ajan kerrostumat näkyvät myös rakenteissa. Halusimme tallentaa näitä muutoksia. Moni informantti konepajalla kertoi siitä, miten heidän työnsä oli muuttunut ja miten tilat olivat siinä samalla muuttuneet. Muutos oli ollut pinnalla jo pitkään.

Konepajan dokumentointi herätti kiinnostusta myös entisissä työntekijöissä. Keskustelu lakkautuksesta ja dokumentointityö osoittivat nopeasti, että tarvetta näyttelylle konepajan historiasta ja nykyhetkestä on. Yleisön tarpeet kuulla ja kertoa konepajan menneisyydestä ja nykyisyydestä laajensivat hankettamme niin, että päätimme kerätä myös muistoja konepajan koko toiminta-ajalta. Tällöin mukaan tulivat myös konepajalaisten asumisen ja harrastamisen tarinat. Samalla täydensimme tietoja vanhoista kuvista.

Konepajan historiaa kerättiin niin arkisto-, kuin kuvalähteistäkin, mutta suurin ja elävin anti tuli informanteilta. Heihin saimme yhteyden järjestämällä Hyvinkään kaupunginmuseon kanssa kaksi muisteluiltaa, jotka tavoittivat hyvin entisiä työntekijöitä ja heidän sukulaisiaan. Ensimmäisessä illassa saimme useita mielenkiintoisia vinkkejä konepajan historiaan liittyen ja kymmeniä nimiä haastateltavien listaan. Toisessa illassa keräsimme erityisesti lisätietoa kokoelmiemme kuvamateriaaliin. Kuvien tunnistuksessa auttoi myös Hyvinkään VR:n eläkeläiset. 


\section{Lopputulos: näyttely ja kartunta}

Kaksivuotinen konepajadokumentointihanke jätti jäljen. Museon kokoelmat karttuivat valtavasti erityisesti valokuvien ja niiden tietosisältöjen osalta. Hyvinkään konepajaan ja VR:n kunnossapidon toimintaan liittyvä historia jäsentyi ja museon kokoelmissa jo ollut aineisto rikastui. Konepajoihin liittyvien kokoelmien luettelointiaste parani huomattavasti. Tämän päivän kunnossapidon tilanne myös selkiytyi museolle.

Konkreettinen ja näkyvä lopputulos on näyttely, joka kertoo menneisyyden ja tämän päivän rautatiekonepaja- ja kunnossapitotyöstä erityisesti Hyvinkään konepajan ja sen työyhteisön kautta.

VR Hyvinkään konepajan merkityksestä työnantajana ja työpaikkana kertoo se, että entiset työntekijät ovat olleet erittäin halukkaita muistelemaan työuraansa ja nykyiset työntekijät ovat suhtautuneet avoimesti työpisteillä tapahtuneeseen dokumentointiin. Kaikesta yhteistyöstä on ilmennyt, että työyhteisö kokee konepajan historian olevan tallentamisen arvoista.

Kartuntana dokumentointihankkeesta on satoja nykydokumentointikuvia, joista loputkin toivottavasti saamme tänä vuonna luetteloitua, useita tunteja videota, dokumentointipäiväkirjoja, haastatteluja, arkistomateriaalia ja joitakin esineitä. Kenttätyöpäivinä otettujen kuvien jälkikäsittelyyn - kuten valintaan, lupakysymyksiin ja luettelointiin - menee yllättävän paljon aikaa. Vain hyvin dokumentoituja kuvia voi hyödyntää tulevaisuudessa. Videomateriaalista on tehty muutama kunnossapitotyön vaiheita kuvaava video näyttelykäyttöön. Museon historiallista konepajakokoelmaa on myös saatu luetteloitua runsaasti, erityisesti vanhoihin kuviin on saatu paljon lisää sisältötietoja.

Museo oppi paljon nykydokumentoinnista. Varsinkin näin pitkässä, laajassa ja monen osallistujan työn ohessa tekemässä hankkeessa suunnitelmien tekeminen ja jatkuva päivittäminen on ensiarvoisen tärkeää, vaikkakin usein vaikeaa. Myös kaiken tapahtuneen tarkka kirjaaminen on välttämätöntä.

Vaikka kuvaaminen olikin vapaata, olisi paremmin etukäteen tehty pohjustus ollut kuvauksia varten hyvä. VR:ää huoletti erityisesti liikesalaisuuksien näkyminen, mutta todellisuudessa suurimmat esteet kuvien julkaisemiselle ovat olleet kuvissa olevien henkilöiden puuttuvat tai puutteelliset turvavarusteet. Lisäksi mahdollisuus kuvaustilanteiden etukäteissuunnitteluun ja kuvakulmien valintaan olisi ollut tärkeä parhaan mahdollisen tuloksen saamiseksi. Usein oli vaikea ennakoida ja saada tietoa, miten joku tietty toimenpide etenee käytännössä.

Luottavaisen ja hyvän ilmapiirin luominen on tärkeää. Monelle ei ole selvää, miten museot toimivat, ja kuulimmekin monta kertaa, että meidän tulee ottaa huomioon erilaiset säädökset ja luvat kuvia julkaistaessa ja muuta sellaista. Siksi yhteisissä palavereissa konepajan johdon kanssa oli hyvä käydä läpi ne periaatteet, joiden mukaan museo toimii ja tekee nykydokumentointia, sekä muistaa kertoa nämä aina uudelleen myös kuvattaville.

Sisäistä ja ulkoista tiedotusta täytyy olla paljon. Parhaaseen tulokseen tässäkin päästiin, kun liikuimme konepajalla paljon ja juttelimme ihmisten kanssa. Näin saimme uusia ja yllättäviäkin kontakteja ja saimme talteen asioita, joita emme olisi itse osanneet kysyä tai etsiä. Aikaa ja resursseja vaativa läsnäolo tuotti hyviä tuloksia.

Halusimme tuottaa tallennettavaan aineistoon monipuolisen ja moniäänisen kuvan ja siksi pyrimme lisäämään konepajan työntekijöiden osallisuutta dokumentointiprosessissa. Lyhyemmässä hankkeessa tämä olisi jäänyt vähäisemmäksi, sillä osallistumaan kannustaminen vaati aikaa sekä monelta osallistujalta asian kypsyttelyä. Suunnittelukäynnit osastoilla 
tekivät meitä ja hankettamme tutuksi, jolloin itse kenttätyöpäivänä oli helpompi lähestyä informantteja, ja he olivat jo ehtineet itsekin miettiä dokumentoitavaa teemaa mielenkiintoisen tallennettavan näkökulman löytämiseksi.

Saimme kokea olevamme monille tärkeä keskustelukumppani ja tunteiden vastaanottaja. Kiinnostuksemme heidän työtään kohtaan sai aikaan positiivisia tuntemuksia ja merkityksellisyyden kokemuksia. Monille oli tärkeää tuoda ilmi ja saada talletettua jälkipolville konepajan ja kunnossapitotyön tärkeys rautatieliikenteen toiminnassa. Moni koki ylpeyttä työstään ja se, että työ tunnustettiin merkitykselliseksi, nosti heidän omanarvontuntoaan tilanteessa, jossa konepajan lakkautuspäätös oli antanut toisenlaisen viestin. Vaikka haastattelut eivät olleet missään nimessä terapeuttisia, on informanttien ollut niiden kautta mahdollista myös ymmärtää ja asettaa oikeisiin mittasuhteisiin tapahtumia ja siten käsitellä tilannetta. Museon vaikuttavuutta olla ihmisille merkitysten antaja ei kannata väheksyä.

Pelastusdokumentoinnissa hyvät ja luottamukselliset suhteet sekä ajan antaminen informanteille auttavat erottamaan katkerat puheenvuorot normaalioloista. Aika mahdollistaa myös hetken dokumentoinnin lisäksi kyselyn normaalioloista ja siten muutoksen tallentamisen.

Konkreettinen ja tärkeä muistutus kaikkia museon tulevia nykydokumentointiprojekteja varten on: Älä koskaan aliarvioi aikaa, joka menee materiaalin jälkikäsittelyyn. Aineiston käytettävyys edellyttää resursseja kerätyn materiaalin jälkikäsittelyyn ja luettelointiin. Myös vanhan aineiston tuntemus on hyödyksi uutta valikoidessa ja luetteloidessa. Linkittämällä aineistot keskenään ne molemmat rikastuvat.

\section{Kirjallisuus}

Huttunen, Kristiina. 2017. Pelastusdokumentoinnin parhaat käytännöt - Kulttuuriperinnön pelastuksen $A B C /$ Tallennus- ja kokoelmayhteistyöverkosto TAKO. Helsinki: Suomen museoliitto, 2017. https://www.museoliitto.fi/index.php?k=12969

Du Riez, Peter, \& Lindgren, Anna (toim.). 2014. Industridokumentation: Hur och varför? Stockholm: Jernkontoret.

Lahtinen, Anu. 2017. Hyvät, pahat ja hyvinkääläiset - Hyvinkään seudun historia. Helsinki: Siltala.

VR Hyvinkään konepaja 1949-1999 - 50-vuotisjuhlanäyttely Suomen Rautatiemuseossa 1999. 2002. Hyvinkää: Suomen Rautatiemuseo.

Borgman, Jarl, \& Nieminen, Pauli (toim.). 1999. VR Hyvinkään konepaja 50 vuotta: 1949-1999. [Hyvinkää]: [VR Hyvinkään konepaja]. 